\title{
Calyceal Diverticulum
}

National Cancer Institute

\section{Source}

National Cancer Institute. Calyceal Diverticulum. NCI Thesaurus. Code C123194.

An out-pouching of the calyx into the renal parenchyma. 